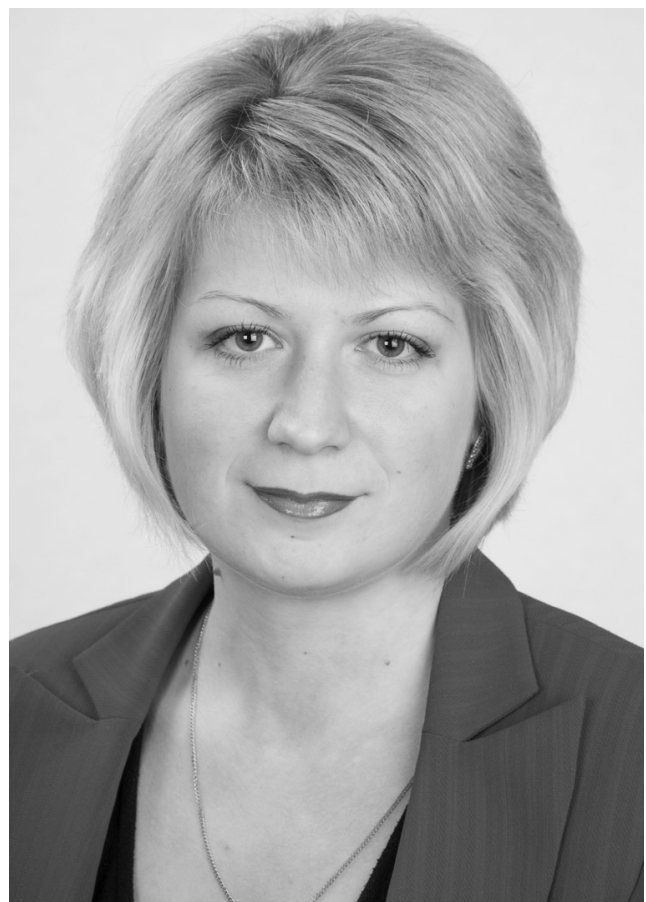

Haiduchenko Svitlana Aleksandrovna,

of Management and Administration, O. M. Beketov National University of Urban Economy in Kharkiv, 61002, Kharkiv, Str. Marshala Bazhanova, 17, tel.: +38 (067) 26113 01, e-mail: gaiduchenko_svet@ukr.net

\title{
ДО ПИТАННЯ РЕАЛІЗАЦІЇ НАРОДНОГО ПРЕДСТАВНИЦТВАУ ВЛАДНИХ СТРУКТУРАХ УКРАЇНИ
}

Анотація. Розглянуто українські історичні особливості народного представництва у владних структурах, проаналізовано прогресивний світовий досвід сучасного демократичного врядування через народне представництво. Відповідно до цього подається бачення шляхів реалізації народного представництва в Україні у контексті сучасних викликів, а саме: глобалізації життєдіяльності світової спільноти; розширення інформаційно-комунікаційного простору у межах мережі Інтернет; осучаснення системи державного управління шляхом її демократизації, децентралізації, демонополізації; інтенсивної трансформації громадянського суспільства в інформаційне; втілення 
у життя ідей парламентаризму тощо. При цьому, враховано історичне підгрунтя українського народного представництва та його сучасні особливості, а також реальні можливості місцевого самоврядування як стовідсоткового народного представництва. Основну увагу зосереджено на інституціональних i нормативно-правових аспектах реалізації феномену народного представництва в Україні у контексті ідей парламентаризму, електронної демократії, компетентнісної та соціокультурної концепцій публічного управління, теорій демократизації виборчого процесу.

Відповідно, розглядаються прагматичні аспекти системного забезпечення відповідного рівня народного представництва у владних структурах України всіх управлінських рівнів шляхом інституціоналізації місцевого самоврядування. Обгрунтовується механізм підвищення ролі інституту місцевого самоврядування шляхом включення його в парламентську систему окремим структурним елементом, який виконуватиме функції “контролера” рівня загальнонаціонального народного представництва, а також відповідального посередника між інститутами держави, бізнесу та громадянського суспільства. Означено аспекти реалізації народного представництва, що сприятимуть формуванню інформаційного суспільства як соціального продукту глобалізації.

Ключові слова: народне представництво, парламентаризм, громадянське суспільство, інформаційне суспільство, публічне управління, місцеве самоврядування, державне управління.

\section{К ВОПРОСУ РЕАЛИЗАЦИИ НАРОДНОГО ПРЕДСТАВИТЕЛЬСТВА ВО ВЛАСТНЫХ СТРУКТУРАХ УКРАИНЫ}

Аннотация. Рассмотрены украинские исторические особенности народного представительства во властных структурах, а также проанализирован прогрессивный мировой опыт современного демократического управления через народное представительство. В соответствии с этим представляется видение путей реализации народного представительства в Украине в контексте современных вызовов, а именно: глобализации жизнедеятельности мирового сообщества; расширение информационно-коммуникационного пространства в рамках сети Интернет; внедрение современных принципов в систему государственного управления путем ее демократизации, децентрализации, демонополизации; интенсивной трансформации гражданского общества в информационное; воплощение в жизнь идей парламентаризма и тому подобное. При этом, учитывается историческая основа украинского народного представительства и его современные особенности, а также реальные возможности местного самоуправления как стопроцентного народного представительства. Основное внимание в исследовании сосредоточено на институциональных и нормативно-правовых аспектах реализации феномена народного представительства в Украине в контексте идей парламентаризма, электронной демократии, компетентностной и социокультурной концепций публичного управления, теорий демократизации избирательного процесса. 
Соответственно, рассматриваются прагматические аспекты системного обеспечения соответствующего уровня народного представительства во властных структурах Украины всех управленческих уровней путем институционализации местного самоуправления. При этом обосновывается механизм повышения роли института местного самоуправления путем включения его в парламентскую систему отдельным структурным элементом, который будет выполнять функции “контролера” уровня общенационального народного представительства, а также ответственного посредника между институтами государства, бизнеса и гражданского общества. Обозначены аспекты реализации народного представительства, которые способствуют формированию информационного общества как социального продукта глобализации.

Ключевые слова: народное представительство, парламентаризм, гражданское общество, информационное общество, публичное управление, местное самоуправление, государственное управление.

\section{TO THE QUESTION OF REALIZATION OF NATIONAL REPRESENTATION IN POWER STRUCTURES OF UKRAINE}

Abstract. In article are considered the Ukrainian historical features of national representation in power structures and also are analysed progressive international experience of modern democratic management through national representation. According to it, vision of ways of realization of national representation in Ukraine in the context of modern challenges is represented, in particular: globalization of activity of the international community; expansion of information and communication space within the Internet; modernization of a system of state administration by its democratization, decentralization, demonopolization; intensive transformation of civil society in information; the embodiment in life of the ideas of parliamentarism and so forth. At the same time, are considered a historical basis of the Ukrainian national representation and its modern features and also real opportunities of local government as absolute national representation. The main attention in a research is concentrated on institutional and standard and legal aspects of realization of a phenomenon of national representation in Ukraine in the context of the ideas of parliamentarism, electronic democracy, competence-based and sociocultural concepts of public management, theories of democratization of electoral process. Agreeably, are considered pragmatical aspects of system ensuring appropriate level of national representation in power structures of Ukraine of all administrative levels by an institutionalization of local government. At the same time, the mechanism of enhancing the role of the institution of local selfgovernment is substantiated by including it in the parliamentary system as a separate structural element that will perform the functions of a "controller" of the level of national representation and a responsible mediator between the institutions of the state, business and civil society. Together, these aspects of the implementation of popular representation contribute to the formation of the information society as a social product of globalization. 
Keywords: national representation, parliamentarism, civil society, information society, public management, local government, public administration.

Постановка проблеми. Сучасна Україна перебуває на порозі реалізації чергового народного волевиявлення щодо виборів його представників у владних структурах і в особі Гаранта Конституції. Успішність і результати цих процесів зумовлені багатьма чинниками, а саме: ціннісні орієнтири розвитку України (національна ідея); політична воля громадян та української еліти; реакція зовнішнього середовища (міжнародної спільноти); інституціональний рівень народного представництва у владних структурах; відповідність нормативно-правового поля виборчого процесу демократичним стандартам, які напрацьовані прогресивними державами. У контексті даного дослідження ключовими прийнято два останніх чинника виборчого дійства.

Аналіз останніх досліджень і публікацій. В періодичних та наукових публікаціях тема народного представництва перебувала та продовжує перебувати у фокусі досліджень різних наукових галузей: політології, соціології, права, державного та публічного управління тощо. 3 позицій демократичного устрою держави народне представництво досліджували такі українські фахівці з державного управління, як: Т. Бутирська, П. Ворона, Н. Грицяк, Ю. Древаль, О. Крутій, В. Куйбіда, О. Мироненко, О. Радченко, С. Серьогін, В. Смолій та ін. Різні аспекти народного представництва були предметом наукового інтересу дослідників у галузі права та політології, зокрема: О. Бандурки, В. Срмолаєва, Н. Заяць, В. Тація та ін. Проте, інституціональні та правові аспекти реалізації феномену народного представництва в Україні залишаються недостатньо дослідженими, а тому досить актуальними у науковому дискурсі. Дослідники представницької демократії майже залишають поза увагою такі їі проблеми, як компетентнісний рівень представництва, його повноту, послідовність забезпечення тощо. Особливу гостроту цим питанням надає розпочатий в Україні процес демократичного державотворення на тлі розгулу корупції та крадіжок державного бюджету України, які відбуваються у наш час "прозоро” для громадянського суспільства.

Мету дослідження пов'язано із пошуком перспективних і науково обгрунтованих напрямів забезпечення відповідного рівня народного представництва у владних структурах України усіх управлінських рівнів у контексті сучасних викликів.

Виклад основного матеріалу дослідження. Народне представництво у владі $є$ демократичним механізмом реалізації інтересів соціальних груп, політичних партій, громадських і бізнесових об’єднань. Дієвість цього механізму зумовлена діалектичним зв'язком змісту та форми суспільного розвитку, що сприяє успішній взаємодії держави із суспільством. Соціально-право- 
вим призначенням народного представництва є вираження соціальних потреб населення через залучення активних громадян до вирішення суспільних життєво важливих питань на демократичних засадах. Сучасна концепція народного представництва є багатоаспектною, тому розглядається прогресивною науковою спільнотою як право народу; як ідея соціальної справедливості; як спосіб здійснення публічної влади; як один із напрямів теорії публічного управління; як принцип взаємовідносин держави та громадянського суспільства, який грунтується на демократичних засадах публічного управління, тощо.

Українське народне представництво у владі має глибоке історичне коріння, яке бере початок з вічової демократії Київської Русі та воєнної демократії Запорізької Січі і аж до нерозвиненого парламентаризму Верховної Ради сучасної України.

Наслідком започаткування практики парламентаризму в новітній історії України стало створення та діяльність протягом березня 1917 квітня 1918 рр. Української Центральної Ради (далі - ЦР) - своєрідного національного парламенту, який пройшов еволюційний шлях від громадсько-політичного об'єднання до представницького органу українського народу [1].

Більш оперативною та дієвою структурою ЦР була Мала Рада, яка спочатку діяла як виконавчий орган і називалась Комітетом ЦР.

Дуже швидко Комітет став керівним органом Центральної Ради, формував ініціативи, які виносилися на розгляд сесій, готував проекти найважливіших рішень i, навіть, проголошував їх іменем Центральної Ради [2]. Як зазначають дослідники, обрання депутатів у ЦР передбачалося за національно-пропорційною системою, що символізувало достатньо демократичний механізм забезпечення прав національних меншин при виборах до законодавчого органу. Право висування кандидатів надавалося партіям та групам виборців за виборчими списками чисельністю біля 200 осіб.

Центральна Рада, як організаційний осередок українського національно-державного відродження, ставила за мету скликання широкого представництва форуму українства, який зробив би i репрезентантом населення України [1].

У дусі вимог парламентаризму складався і депутатський статус членів Центральної Ради, котрі повинні були працювати на постійній основі. Їм надавалися широкі гарантії для виконання депутатських обов’язків, забезпечувалася депутатська недоторканість [3].

Відповідно до “Проекту Основних законів Української держави” відбувалися спроби реалізації ідеї парламентаризму також в добу Гетьманату та Директорії шляхом впровадження двопалатної структури парламенту.

Згідно $з$ Проектом його верхню палату - Державну Раду - складали б 150 “найкращих і найрозумніших”людей країни, рекомендованих земським зібранням, міськими радами, кошовими радами, сенатом. Третина $з$ них призначалася гетьманом довічно, а 100 осіб мало обиратися на 6 років земським та козацьким зібраннями. Нижню палату - Раду 
депутатів (600 осіб) - передбачалося обирати населенням на 4 роки [4].

У період національно-визвольних подій 1917-1921 років на українських землях формувалися ще Українські Національні Ради (в УНР, ЗУНР) та інші органи представницького характеру, які мали ознаки обмеженого парламентаризму. Цей досвід українського державотворення має велике історичне значення, тому знайшов своє відображення в діяльності сучасної Верховної Ради України.

Результати аналізу історичних етапів розвитку народного представництва в Україні засвідчили, що зміст народного представництва, який традиційно пов’язувався 3 колегіальними представницькими органами влади, і з часом еволюціонував і доповнився (крім Верховної Ради України та органів місцевого самоврядування) ще й одноосібним виборним інститутом влади - інститутом Президента України. До того ж, глобалізація суттєво вплинула на зміст народного представництва у контексті забезпечення прав людини та громадянина; формування інституту народного представництва та його впровадження в систему публічного управління.

Така практика конституційного права делегування народом своїх владних повноважень представницьким органам публічної влади $€$ звичною і для інших прогресивних країн світу. Утім, в силу історичних особливостей розвитку державотворення, Україна значно відстає від цих країн у реалізації демократичних принципів публічного управління, що виявляється в обмеженій можливості здійснення громадського контролю за діяльністю уряду; у відсутності індивідуальної та колективної відповідальності Президента, депутатів Верховної Ради, членів Уряду України за негативні соціально-економічні та політичні наслідки ї діяльності; у прагненні держави до монополізації інформаційної сфери; у перевагах адміністративних ресурсів у виборчих процесах; у відсутності державних механізмів формування інформаційного громадянського суспільства тощо. Сучасні українські реалії доводять, що у сукупності це призводить до різкого послаблення влади, дезорганізації життєдіяльності країни, розколу та протистояння у суспільстві, економічної та політичної кризи, навіть, часткової втрати суверенітету.

За цих умов, нагальними залишаються питання відносин, що склалися в Україні між різними гілками влади та первинним органом публічної влади (первинною ланкою народного представництва) - місцевим самоврядуванням. Рішення цих питань лежить, передусім, у правовій площині функціонування місцевого самоврядування. За конституційними нормами України представницькі органи місцевого самоврядування входять лише до системи органів муніципального утворення, тому вони майже не впливають на загальнодержавні управлінські рішення та законотворчий процес. Такий стан справ стримує розвиток публічного управління в Україні.

Відповідно до цього, цілком слушною є наукова думка, що “лише через проведення системних реформ представницької влади можна 
прискорити формування громадянського суспільства, зокрема, через децентралізацію державної влади та деконцентрацію владних повноважень, що має зміцнити організаційну, матеріально-фінансову та правову самостійність місцевих влад, які є основною передумовою ефективного розвитку представницької влади в регіонах"[4].

Реалізація системних реформ представницької влади зумовлює, у першу чергу, залучення місцевого самоврядування до законотворчого процесу через формування окремої палати у Верховній Раді України. На разі, цілком очевидним є факт, що правова невизначеність законотворчої діяльності представницьких інституцій нижчої ланки дозволяє парламентарям Верховної Ради перевищувати свої повноваження та призводить не лише до порушення законності та конституційних засад, а й взагалі, до нівелювання концепції народного представництва. Це неприпустимо, тому що Верховна Рада як парламент, заснований в Україні з дня встановлення іï незалежності, покликана реалізовувати інституціоналізацію панівних інтересів і цінностей, політичних орієнтирів і настроїв усього суспільства, а не його олігархічних груп. Отже, стратегічною місією парламенту, як інституту громадянського суспільства, є поєднання двох феноменів - суверенітету народу та державної влади, що і надає системі публічного управління демократичного характеру, а самому парламенту - широкої соціальної доступності та відкритості.

Практика народного представництва у прогресивних країнах світу свідчить, що найважливішим показником демократизації державного управління є роль і місце в структурі політичних інститутів саме законодавчої влади. Це зумовлено тим, що у розвиненій демократичній державі парламент представляє інтереси всіх груп населення, які через цей інститут отримують можливість впливати на прийняття важливих управлінських рішень державою.

В умовах проведення адміністративних та політичних реформ в Україні відбуваються досить складні та неоднозначні процеси політико-правової трансформації державної влади регіонального рівня, які потребують досить оперативного законодавчого забезпечення. На думку переважної більшості дослідників, відповідна оперативність у формуванні нормативно-правового поля діяльності органів публічної влади може бути забезпечена тільки зусиллями первинної ланки народного представництва - місцевим самоврядуванням. Сучасний український парламентаризм більшість дослідників характеризують як інституціонально сформовану, але змістовно недоопрацьовану систему владних відносин, яка базується на формальному визнанні демократичних засад взаємодії держави із громадянським суспільством. Тому життєво важливими видаються заходи, спрямовані на підвищення рівня представницького корпусу Верховної Ради України, як органу народовладдя, що функціонує на засадах парламентаризму, визнаних прогресивною міжнародною спільнотою.

За цих умов, стають актуальними такі заходи щодо вирішення проблем 
представницької місії Верховної Ради України (далі - ВРУ): обгрунтування та визначення місця ВРУ в системі публічного управління; конституційне утвердження ВРУ не лише єдиним законодавчим органом влади, а й єдиним представницьким органом; удосконалення механізму реалізації народного представництва; пошук інноваційних механізмів забезпечення сучасного рівня народного представництва у контексті формування громадянського інформаційного суспільства. У сукупності такі заходи сприятимуть забезпеченню реального народного представництва та функціонуванню парламенту як представницького інституту влади.

Отже, цілком природно, що наукове обгрунтування та визначення місця ВРУ в системі публічного управління напряму пов'язано із проблемою поєднання безпосередньої та представницької демократії. Українські суспільно-політичні реалії вказують на необхідність реформування місцевого самоврядування в Україні, наповнення його реальним змістом, підвищення ролі представницьких органів місцевого самоврядування, як найбільш дієвого виразника волі членів територіальної громади та самого дієвого контролера якості загальнонаціонального народного представництва.

У свою чергу, підвищення ролі місцевого самоврядування шляхом включення до складу парламенту дасть підстави для конституційного утвердження ВРУ єдиним представницьким органом, що усуне існуючу в Україні проблему дуалізму влади та забезпечить дієздатність держави у контексті потреб людини та громадянина. Зрозуміло, що такий підхід до формування парламенту зумовлює модернізацію організаційної структури ВРУ та її функціональних зв'язків.

Слід зазначити, що ідея запровадження в Україні двопалатного парламенту за часи іï незалежності уже була озвучена в проектах Конституції України та дискутувалась у науковому просторі. Утім, для втілення цієї ідеї у життя на той час було недостатньо передумов, а от останні українські реалії та рівень передвиборчих процесів свідчать про те, що така ідея є на часі.

Згідно $з$ досвідом прогресивних країн світу, інституціоналізація регіональної участі в народному представництві забезпечується через формування другої (нижньої) палати парламенту. Її формування базується на принципах регіонального представництва 3 певним набором значущих для країни та регіонів повноважень, визначених за принципом субсидіарності. У контексті історичних особливостей України цілком доцільною може бути модель парламенту, за якої друга (нижня) палата, як і перша - верхня, також формуватиметься за допомогою прямих загальних виборів одночасно із виборами до представницьких органів місцевого самоврядування. Утім, термін діяльності нижньої палати має бути менший на 1-2 роки, ніж термін діяльності верхньої палати (загальнонаціональних представників країни), який доцільно було б подовжити до 6-ти років. Такий підхід до формування парламенту забезпечує максимальну спадкоєм- 
ність і демократичність публічного управління, а також безпосередню залежність й відповідальність депутатів перед виборцями у процесі реалізації інтересів регіональних спільнот. Крім цього, цілком логічним видається втілення у життя ідеї делегування повноважень верхній палаті парламенту щодо виборів “отаманів" - Президента України, Прем’єр-міністра, Голови Верховної Ради. Саме таким чином може сформуватися парламентська модель публічного управління, яка покладе край існуючій в Україні практиці боротьби за владу між Президентом і Головою Уряду, а також додаткових і досить великих витрат бюджету на виборчі процеси. До того ж, за таких умов значно спрощується процедура імпічменту Президента, у разі невиконання обов'язків Гаранта Конституції України, що на даний час є дуже актуальним, а також інституціоналізується технологія формування парламентської більшості, яка бере на себе відповідальність за результати діяльності “отаманів”. Іншими словами, в умовах публічного управління має переважати колегіальне управління життєдіяльністю громадянського суспільства, що відроджує вікові традиції українського державотворення.

Відповідно до цього, критичними стають принципи організації та реалізації виборчого процесу. Поряд із такими загальними принципами, як законність; загальність; таємність волевиявлення; добровільність та особистість виборчого права; гласність; періодичність і обов’язковість публічних виборів, особливого значення набувають принципи забез- печення рівного права громадських об'єднань на участь у народному представництві поряд із політичними партіями.

Дослідники розглядають вибори як соціальний механізм, який забезпечує формування влади, реалізуючи сутність громадянського суспільства; формує політичні еліти; забезпечує процес соціалізації особистості; здійснюе контроль і регулювання влади громадянами; відображує суспільні настрої тощо. Успішна реалізація виборчого процесу залежить від рівня нормативно-правової бази забезпечення цього дійства; наявності усталених демократичних традицій проведення виборів; характеристик діючого політичного режиму державного управління; рівня масової i, зокрема, правової культури усіх учасників виборчого процесу тощо [5]. Особливість інституту виборів у системі народного представництва в Україні полягає в тому, що він включає громадські структури.

За своєю соціальною природою, низка проблем виборчих технологій хоч і висвітлена значною кількістю наукових публікацій та дискусій, проте не втрачає своєї актуальності і у наш час. На разі, ключовими з цих проблем залишаються правові складові, які визначають різні аспекти виборчого процесу досить суперечливо та неповно, зокрема, щодо введення сучасних електронних методів у процес народного волевиявлення на виборах; удосконалення конституційно-правового механізму своєчасного призначення виборів і забезпечення ротації народного представництва; врахування інтересів виборців че- 
рез оптимізацію бюджетного фінансування партійного й громадського представництва; правового забезпечення порядку передвиборної агітаціï, процедур голосування та підрахунку голосів виборців тощо.

У разі впровадження двопалатного парламенту, в Україна може дійти консенсус між прихильниками використання пропорційної виборчої системи (за партійними списками) та мажоритарної системи. Пропорційна система сприяє представництву у парламенті не лише більшості, але й виборцям, які опинилися в меншості. Мажоритарна система надає представництва лише більшості виборців, проте, має такі переваги, як незалежність, самостійність, індивідуальна відповідальність народного обранця. Отже, цілком логічно у процесі виборів представників Верхньої палати Верховної Ради України (у разі прийняття відповідного Закону) використовувати пропорційну виборчу систему, а при виборах представників Нижньої палати та у виборні органи місцевого самоврядування - мажоритарну систему.

Українські дослідники вважають мажоритарну виборчу систему більш демократичною, оскільки вона дозволяє громадянам обирати до представницьких органів влади не лише кандидатів від політичних партій, а й представників прогресивної громадськості. Відповідно, така виборча система не тільки не перешкоджає, а й сприяє діяльності політичних партій, адже вони можуть висувати та підтримувати своїх кандидатів у виборчих округах.

Оптимізація виборчої системи народного представництва в Укра- їні пов'язана із наступними заходами: модернізацією організаційної структури Верховної Ради України та її функціональних зв'язків; диференціацією прохідного бар'єру; формуванням регіональних виборчих списків; запровадженням мажоритарної виборної системи на виборах депутатів Нижньої палати Верховної Ради України, місцевих рад, а також сільських, селищних та міських голів; відновленням пропорційної системи представництва у Верхній палаті Верховної Ради України.

У контексті відповідальності українських можновладців значно загострюється питання забезпечення демократизації судової влади в Україні. В критичних умовах тотальної недовіри українців до судової влади, залучення місцевого самоврядування до законотворчої діяльності та прийняття управлінських рішень сприятиме зміцненню народного контролю за процесом правосуддя через законне гарантування діяльності народних засідателів і присяжних, яких обирають громадяни. Характерно, що суди присяжних поширені майже в усіх прогресивних державах світу, а західні законотворці, навіть, висувають пропозиції щодо запровадження принципу виборності суддів.

Як показав досвід розвинутих країн, цивілізований рівень парламентаризму забезпечується зрілою політичною структурованістю та волею суспільства; домінуючим типом партійної системи; рівнем політичної, правової й організаційної культури як управлінської еліти, так і електорату. У країнах, що стають на шлях демократичного роз- 
витку, саме парламент відображає всю складність, суперечливість і конфліктність суспільного стану. Слід також враховувати, що діяльність парламенту в турбулентних умовах нашої сучасності не завжди встигає за динамікою політичних i суспільних трансформацій, тому часто стає стримуючим чинником демократичного розвитку країни. Саме цей факт стає провокуючим чинником нестабільності у суспільстві багатьох країн, навіть, самих розвинених.

За цих умов критичним стає пошук інноваційних механізмів забезпечення сучасного рівня народного представництва у контексті державної політики формування громадянського інформаційного суспільства як соціального продукту глобалізаціï. Ці механізми є багатоаспектними й охоплюють управлінську, соціальну, політичну, економічну, науково-технічну, правову, освітню та інші сфери діяльності. При цьому, головною умовою їх дієвості мають стати культурна та демократична інституціоналізація національно-історичної специфіки, забезпечення спадкоємності та культивування традиції врядування. Як доводить практика публічного управління у розвинутих країнах, бездумне копіювання зарубіжних технологій формування громадянського інформаційного суспільства і його представництва у владних структурах не принесе очікуваних результатів. Саме цим можна пояснити низький рівень дієвості та результативності “Стратегії розвитку інформаційного суспільства в Україні” [6], прийнятої у травні 2013 року.
У такому зв'язку актуалізується необхідність розробки українською науковою спільнотою та управлінцями-практиками сучасної національної Стратегії, яка визначить повний комплекс механізмів формування не тільки і не стільки інформаційного суспільства, скільки громадянського суспільства як ключового чинника публічного управління, а також відповідного рівня народного представництва у владних структурах.

Такий документ є конче необхідним для формування державної та регіональної політики України щодо інституціоналізації та технічного забезпечення електронного урядування; освітньої та просвітницької роботи серед населення 3 метою формування громадянського інформаційного суспільства; залучення молоді до прийняття управлінських рішень не тільки на місцевому, а й на загальнодержавному рівні; формування організаційної культури публічного управління та масової національної культури як ключових чинників незалежності та конкурентоспроможності України, а також їі сталого розвитку, окресленого Цілями на 2016 - 2030 роки, які задекларовані Генеральною Асамблеєю ООН у вересні 2015 року.

Висновки та перспективи подальших досліджень. Таким чином, формування народного представництва у владних структурах України у контексті реалізації принципів демократії та парламентаризму може базуватися як на власному історичному досвіді, так і на досвіді прогресивних держав світу, адаптованого до українських реалій. При цьому вкрай актуальними постають 
рішення проблем українського державотворення шляхом підвищення рівня українського парламенту завдяки інституціоналізації місцевого самоврядування як народного представництва, а також формування громадянського інформаційного суспільства. Основою інновацій, що стосуються загальнодержавного народного представництва, мають стати правова та культурна інституціоналізація національно-історичної специфіки врядування; забезпечення спадкоємності й культивування традиції державного (публічного) управління, що є головним чинником дієвості будь-яких правових реформ, а також удосконалення виборчого законодавства як стратегічного чинника реалізації народного волевиявлення.

\section{СПИСОК ВИКОРИСТАНИХ ДЖЕРЕЛ}

1. Лісова К. С. Втілення ідеї парламентаризму в період Української революції (1917-1921рр.) Теорія та історія держави і права. Філософія права / К. С. Лісова // Часопис Київського ун-ту права. К., 2015. Вип. 2. С. 20-25.

2. Рум'янцев В. Центральна Рада: становлення українського парламентаризму / В. Рум'янцев // Вісник Академії правових наук України. 1997. Вип. 4. С. 69-74.

3. Журавський В. С. Розвиток теорії і практики українського парламентаризму в 1917-1921 pp. / В. С. Журавський // Вісник Нац. ун-ту внутрішніх справ. Х., 2001. Вип. 13. С. 170175.

4. Срмолаєв В. М. Історія вищих представницьких органів влади в Украї- ні: навч. посіб. / В. М. Єрмолаєв. Х.: Право, 2007. 277 с.

5. Ворона П. В. Особливості становлення та розвитку представницької влади в Україні (на прикладі місцевого самоврядування) / П. В. Ворона // Теорія та практика державного управління. 2011. Вип. 4 (35). C. 333-338.

6. Про Схвалення Стратегії розвитку інформаційного суспільства в Україні : розпорядження Кабінету Міністрів України від 15 травня 2013 р. № 386-р [Електронний ресурс]. Режим доступу : http://zakon3. rada.gov.ua/laws/show/386-2013$\% \mathrm{D} 1 \% 80$

\section{REFERENCES}

1. Lisova K. S. (2015). Vtilennya ideyi parlamentaryzmu $v$ period Ukrayinskoyi revolyuciyi (1917-1921 rr.) [Implementation of the idea of parliamentarism during the Ukrainian revolution (1917-1921)]. Teoriya ta istoriya derzhavyi prava. Filosofiya prava - The Theory and history of state and law. Legal philosophy. (Vols. 2), (p. 20-25). Kyiv [in Ukrainian].

2. Rumiantsev V. (1997). Centralna Rada: stanovlennya ukrayinskogo parlamentaryzmu [Central Rada: formation of the Ukrainian parliamentarism]. Visnyk Akademiyi pravovyx nauk Ukrayiny - Visnyk of Academy of legal sciences of Ukraine. (Vols. 4), (p. 6974). Kyiv [in Ukrainian].

3. Zhuravskii V. S. (2001). Rozvytok teoriyi i praktyky ukrayinskogo parlamentaryzmu v 1917-1921 [Development of the theory and practice of the Ukrainian parliamentarism in 1917-1921]. Visnyk Nacionalnogo universytetu vnutrishnix sprav - Visnyk of the National university of internal affairs. (Vols. 13), (p. 170-175). Kharkiv [in Ukrainian].

4. Yermolaiev V. M. (2007). Istoriya vyshhyx predstavnyczkyx organiv vlady 
v Ukrayini [History of the supreme representative bodies of the power in Ukraine]. Kharkiv: Law [in Ukrainian].

5. Vorona P. V. (2011). Osoblyvosti stanovlennya ta rozoytku predstavnyczkoyi vlady v Ukrayini (na prykladi miscevogo samovryaduvannya) [Features of formation and development of the representative power in Ukraine (on the example of local government)]. Teoriya ta praktyka derzhavnogo upravlinnya The theory and practice of public ad- ministration (Vols. 4 (35), (p. 333338). Kharkiv: Master [in Ukrainian].

6. Pro Sxvalennya Strategiyi rozvytku informacijnogo suspilstva v Ukrayini : rozporyadzhennya Kabinetu Ministriv Ukrayinyvid 15 travnya 2013 r. № 386-r [About approval of the Development strategy of information society in Ukraine: order of the Cabinet of Ministers of Ukraine of May 15, 2013 № 386-r]. (May 15, 2013). zakon.rada. gov.ua. Retrieved from http://zakon3. rada.gov.ua/laws/show/386-2013-p 